Beiträge zur Tabakforschung International · Contributions to Tobacco Research Volume $19 \cdot$ No. $1 \cdot$ April 2000

DOI: $10.2478 / \mathrm{cttr}-2013-0692$

\title{
Determination of Dibenzacridines in the Particulate Phase of Cigarette Smoke*
}

\author{
by \\ Tania A. Sasaki and Serban C. Moldoveanu \\ Brown and Williamson Tobacco Corporation \\ 2600 Weaver Road \\ Macon, GA 31217
}

\section{SUMMARY}

This study attempted to resolve a controversy related to the presence of dibenz $[a, j]$ acridine and dibenz $[a, h]$ acridine in the particulate phase of cigarette smoke. Smoking was performed using FTC conditions $(35 \mathrm{~mL}$ puff volume, $2 \mathrm{~s}$ puff, 1 min interval) on a Borgwaldt RM 20/CS smoking machine. The particulate phase of forty cigarettes was collected on $92 \mathrm{~mm}$ Cambridge filter pads. Pads were combined to analyze the particulate phase of the mainstream smoke from between 120 and 320 cigarettes. In an initial scheme of analysis, the pads were extracted with an acidic aqueous solution. This aqueous solution was then washed with $\mathrm{CH}_{2} \mathrm{Cl}_{2}$ and the organic phase discarded. The aqueous solution was then changed to basic and extracted with $\mathrm{CH}_{2} \mathrm{Cl}_{2}$, which was concentrated and analyzed via GC/MS. The dibenzacridine could not be detected utilizing this scheme, even when the pads had been spiked with a few thousand nanograms of dibenzacridine. After using several other organic solvents (cyclohexane, $\mathrm{CHCl}_{3}$, and benzene) to eliminate the possibility that the extraction efficiency of $\mathrm{CH}_{2} \mathrm{Cl}_{2}$ was poor, it was determined that dibenzacridine was being discarded with the first $\mathrm{CH}_{2} \mathrm{Cl}_{2}$ wash. A successful separation scheme was developed by extracting the smoked pad with an aqueous acidic solution, followed by extraction of the aqueous phase with $\mathrm{CH}_{2} \mathrm{Cl}_{2}$ without $\mathrm{pH}$ change. The $\mathrm{CH}_{2} \mathrm{Cl}_{2}$ extract was concentrated under nitrogen and $1 \mu \mathrm{L}$ injected for GC/MS analysis. Quantification was achieved by spiking the pads with dibenz $[a, j]$ acridine $-d_{13}$ as an internal standard at a level equal to $1.7-2.5 \mathrm{ng} / \mathrm{cig}$. The limit of detection for this technique was approximately $0.5 \mathrm{ng} / \mathrm{cig}$. The chromatographic separation was performed with a $30 \mathrm{~m} \mathrm{BPX}-5$ column $(0.25 \mathrm{~mm}$ i.d., 0.25 $\mu \mathrm{m}$ film thickness). Mass spectral data were acquired in selected ion monitoring (SIM) mode with $\mathrm{m} / \mathrm{z}=279$ for the two dibenzacridine isomers and $\mathrm{m} / \mathrm{z}=292$ for the deuterated internal standard. Three commercial cigarettes were analyzed: two commercial Full Flavor cigarettes, one commercial Light cigarette, and a $1 \mathrm{R} 4 \mathrm{~F}$ reference cigarette. Neither dibenzacridine isomer was detected in any of the samples analyzed. [Beitr. Tabakforsch. Int. 19 (2000) 25-31]

\section{ZUSAMMENFASSUNG}

Diese Studie soll ein Beitrag zur Lösung einer Kontroverse bezüglich der Anwesenheit von Dibenz $[a, j]$ acridin und Dibenz $[a, b]$ acridin in der Partikelphase des Cigarettenrauchs sein. Das Abrauchen der Cigaretten erfolgte nach FTC-Bedingungen (Zugvolumen $35 \mathrm{~mL}$, Zugdauer 2 Sek., Zugintervall 1 Min.) mit einer Borgwaldt RM 20/CS Rauchmaschine. Die Partikelphase von je 40 Cigaretten wurde auf $92 \mathrm{~mm}$ Cambridgefiltern gesammelt. Zur Analyse der Partikelphase des Hauptstromrauchs von 120 bis 320 Cigaretten wurden mehrere Cambridgefilter untersucht. In einem ersten Schritt wurden die Cambridgefilter mit einer sauren wäßrigen Lösung extrahiert. Diese wäßrige Lösung wurde anschließend mit $\mathrm{CH}_{2} \mathrm{Cl}_{2}$ gewaschen, und die organische 
Phase wurde verworfen. Die wäßrige Lösung wurde dann alkalisch gemacht und mit $\mathrm{CH}_{2} \mathrm{Cl}_{2}$ extrahiert, das konzentriert und mittels GC/MS analysiert wurde. Bei diesem Verfahren konnte kein Dibenzacridin nachgewiesen werden, auch dann nicht, wenn den Cambridgefiltern mehrere Tausend Nanogramm Dibenzacridin zugesetzt wurde. Nach Verwendung mehrerer anderer organischer Lösungsmittel (Cyclohexan, $\mathrm{CHCl}_{3}$ und Benzol), um die Möglichkeit auszuschließen, dass die Extraktionsfähigkeit von $\mathrm{CH}_{2} \mathrm{Cl}_{2}$ zu gering ist, wurde gefunden, dass das Dibenzacridin beim ersten $\mathrm{CH}_{2} \mathrm{Cl}_{2}$-Waschvorgang verloren ging. Es wurde ein erfolgreiches Trennungsverfahren entwickelt, bei dem der Cambridgefilter mit einer sauren wäßrigen Lösung extrahiert wurde, gefolgt von der Extraktion der wäßrigen Phase mit $\mathrm{CH}_{2} \mathrm{Cl}_{2}$ ohne $\mathrm{pH}$ - ̈̈nderung. Anschließend erfolgte Konzentration unter Stickstoff und Injektion von $1 \mu \mathrm{L}$ der Lösung für die GC/MS-Analyse. Für die quantitative Bestimmung wurde den Cambridgefiltern als interner Standard Dibenz $[a, j]$ acridin- $d_{13}$ in einer Menge zugesetzt, die 1,7-2,5 ng/Cig. entspricht. Die Nachweisgrenze für dieses Verfahren betrug etwa 0,5 ng/Cig. Die chromatographische Auftrennung erfolgte mittels einer $30 \mathrm{~m}$ BPX-5-Säule (Innendurchmesser 0,25 mm, Filmdicke 0,25 $\mu \mathrm{m}$ ). Die Massenspektraldaten wurden im SIM-Betrieb (selected ion monitoring) unter Verwendung von $\mathrm{m} / \mathrm{z}=279$ für die beiden Dibenzacridin-Isomere und $m / z=292$ für den deuterierten internen Standard gemessen. Es wurden drei handelsübliche Cigaretten analysiert: zwei handelsübliche Full Flavour Cigaretten, eine handelsübliche Leichtcigarette und eine 1R4F-Vergleichscigarette. In keiner der analysierten Proben wurde eines der Dibenzacridin-Isomere nachgewiesen. [Beitr. Tabakforsch. Int. 19 (2000) 25-31]

\section{RESUME}

Le but de cette étude est d'élucider la controverse relative à la présence de dibenzo[ $[a, j]$ acridine et de dibenzo $[a, b]$ acridine dans la phase particulaire de la fumée de cigarette. Les cigarettes ont été fumées sur une machine à fumer Borgwaldt RM 20/CS selon les conditions de la Federal Trade Commission (FTC) (volume de bouffée: $35 \mathrm{~mL}$, durée de bouffée: 2 secondes, fréquence de bouffée: 1 minute). La phase particulaire de 40 cigarettes a été recueillie sur des filtres Cambridge de $92 \mathrm{~mm}$. Un ensemble de plusieurs filtres Cambridge, sur lesquels était recueillie la phase particulaire de la fumée du courant principal de 120 à 320 cigarettes, a été analysé. Dans un premier temps, l'extraction des filtres avait été réalisée avec une solution aqueuse acide, qui était ensuite lavée au $\mathrm{CH}_{2} \mathrm{Cl}_{2}$, la phase organique étant alors jetée. La solution aqueuse était ensuite changée en solution basique, et l'extraction se faisait au $\mathrm{CH}_{2} \mathrm{Cl}_{2}$, avec concentration et analyse par GC/MS. La dibenzoacridine n'était pas détectée par cette méthode, de même lorsque les filtres Cambridge étaient imprégnés de quelques milliers de nanogrammes de dibenzo-acridine. A la suite de l'utilisation de plusieurs autres solvants organiques (cyclohexane, $\mathrm{CHCl}_{3}$, et benzène) pour éliminer la possibilité de l'inefficacité de l'extraction au $\mathrm{CH}_{2} \mathrm{Cl}_{2}$, il a été déterminé que la dibenzo-acridine était rejetée par le premier lavage au $\mathrm{CH}_{2} \mathrm{Cl}_{2}$. Une méthode satisfaisante de séparation a été mise au point, consistant en une extraction des filtres Cambridge avec une solution acide aqueuse, suivi par l'extraction de la phase aqueuse au $\mathrm{CH}_{2} \mathrm{Cl}_{2}$ sans changer le $\mathrm{pH}$, puis par une concentration à l'azote et l'injection de $1 \mu \mathrm{L}$ de la solution pour l'analyse par GC/MS. La quantification a été réalisée en imprégnant les filtres Cambridge avec de la dibenzo[ $[a, j]$ acridine- $d_{13}$ comme étalon interne, et à une quantité qui correspondait à 1,7-2,5 ng/cig. La limite de détection de cette technique était d'environ 0,5 $\mathrm{ng} / \mathrm{cig}$. La séparation chromatographique a été réalisée à l'aide d'une colonne BPX-5 de $30 \mathrm{~m}$ (diamètre intérieur $=0,25 \mathrm{~mm}$, épaisseur $\mathrm{du}$ film $=0,25 \mu \mathrm{m})$. Les données d'analyse par spectrométrie de masse ont été obtenues en mode de contrôle ionique spécifique (SIM = selected ion monitoring), avec $\mathrm{m} / \mathrm{z}=279$ pour les deux isomères de dibenzo-acridine et $\mathrm{m} / \mathrm{z}=292$ pour le standard deutéré interne. Trois cigarettes vendues dans le commerce ont été analysées: deux cigarettes plein arôme, une cigarette légère et une cigarette de référence Kentucky 1R4F. Aucun des deux isomères de dibenzoacridine n'a été détecté dans les échantillons analysés. [Beitr. Tabakforsch. Int. 19 (2000) 25-31]

\section{INTRODUCTION}

Dibenz $[a, j]$ acridine and $\operatorname{dibenz}[a, h]$ acridine have been reported as present in smoke condensate in a 1960 publication by VAN DUUREN et al. (1). Also, unpublished data of CANDELI et al. were reported by WYNDER and HOFFMANN (2) in 1967, who again indicated the presence of these compounds in smoke. In a list of tobacco smoke components published in 1998 by HOFFMANN and HOFFMANN (3), dibenz[ $[a, j]$ acridine was included as being present at 3-10 ng/cig. However, as reported by RODGMAN (4) in 1998, a series of seven independent studies performed by KABURAKI et al. (5), SCHMELTZ et al. $(6,7)$, SNOOK et al. $(8,9)$, GRIMMER et al. (10), and KAMATA et al. (11), failed to find this substance in smoke. The controversy about the presence of dibenzacridines in smoke is also discussed in a recent monograph on tobacco (12). The work presented here is intended to resolve the problem and attempted to detect the presence of dibenzacridines in the particulate phase of cigarette smoke. In their 1960 study, VAN DUUREN et al. (1) also reported the presence of dibenzocarbazole in cigarette smoke. After some preliminary investigation, the present study shows that it is not possible to detect this substance with Van Duuren's procedure. 


\section{EXPERIMENTAL METHOD}

\section{Materials}

All solvents utilized were spectral grade. Dibenz $[a, j]$ acridine, dibenz $[a, b]$ acridine, and $7 H$-dibenzo[c,g]carbazole were purchased from Promochem (Laramie, W.Y., USA). Dibenz[ $[a, j]$ acridine- $d_{13}$ and $7 \mathrm{H}$ dibenzo $[c, g]$ carbazole- $d_{12}$ were used as internal standards and both were purchased from Cambridge Isotope Laboratories, Inc. (Andover, M.A., USA).

\section{Cigarette samples}

The mainstream smoke from three commercial cigarettes and 1R4F reference cigarettes were analyzed. All cigarettes were king size and filtered. Commercial cigarette A was a Full Flavor cigarette and commercial cigarette $\mathrm{B}$ was a Light. They reportedly yield $17.5 \mathrm{mg}$ and $11.1 \mathrm{mg}$ total particulate matter (TPM), respectively. Commercial cigarette $\mathrm{C}$ was a Full Flavor, $100 \%$ natural tobacco product with a reported TPM value of $17.4 \mathrm{mg}$. The reported TPM value for $1 \mathrm{R} 4 \mathrm{~F}$ reference cigarettes is $11.0 \mathrm{mg}$.

\section{Smoking and TPM collection}

All smoking was done under FTC specifications ( $35 \mathrm{~mL}$ puff volume, $2 \mathrm{~s}$ puff duration, 1 min interval) on a Borgwaldt RM 20/CS smoking machine. The TPM from forty cigarettes was collected on a single $92 \mathrm{~mm}$ Cambridge filter pad. Pads were combined to yield TPM from a total of between 120 and 320 cigarettes.

\section{Sample extraction and preparation}

The initial extraction procedure started with smoking 40 cigarettes onto a Cambridge pad. The pad was spiked with $4000 \mathrm{ng}$ of a standard solution of dibenz $[a, j]$ acridine to determine if, and to what efficiency, the analyte would be extracted with this procedure. After spiking, the pad was extracted three times with $50 \mathrm{~mL}$ of a $0.1 \mathrm{~N} \mathrm{HCl}$ solution in water. The extraction was done on a wrist shaker for 20 minutes and the liquid was vacuum filtered. Then, the acidic aqueous solution was washed two times with about 20 $\mathrm{mL} \mathrm{CH} \mathrm{Cl}_{2}$ and the organic phase was discarded. After this clean-up step, the $\mathrm{pH}$ of the solution was changed to basic with $\mathrm{NaOH}$, followed by extraction of this aqueous solution three times with $10 \mathrm{~mL} \mathrm{CH}_{2} \mathrm{Cl}_{2}$. The $\mathrm{CH}_{2} \mathrm{Cl}_{2}$ extracts were combined and evaporated under a stream of nitrogen to a final volume of $1 \mathrm{~mL}$ and $1 \mu \mathrm{L}$ of this solution was injected into the GC/MS for analysis. This scheme (Scheme A) is shown in Figure 1. Scheme A was unsuccessful in extracting the standard from a smoke pad. It was determined that the analyte was getting discarded with the first $\mathrm{CH}_{2} \mathrm{Cl}_{2}$ wash, so

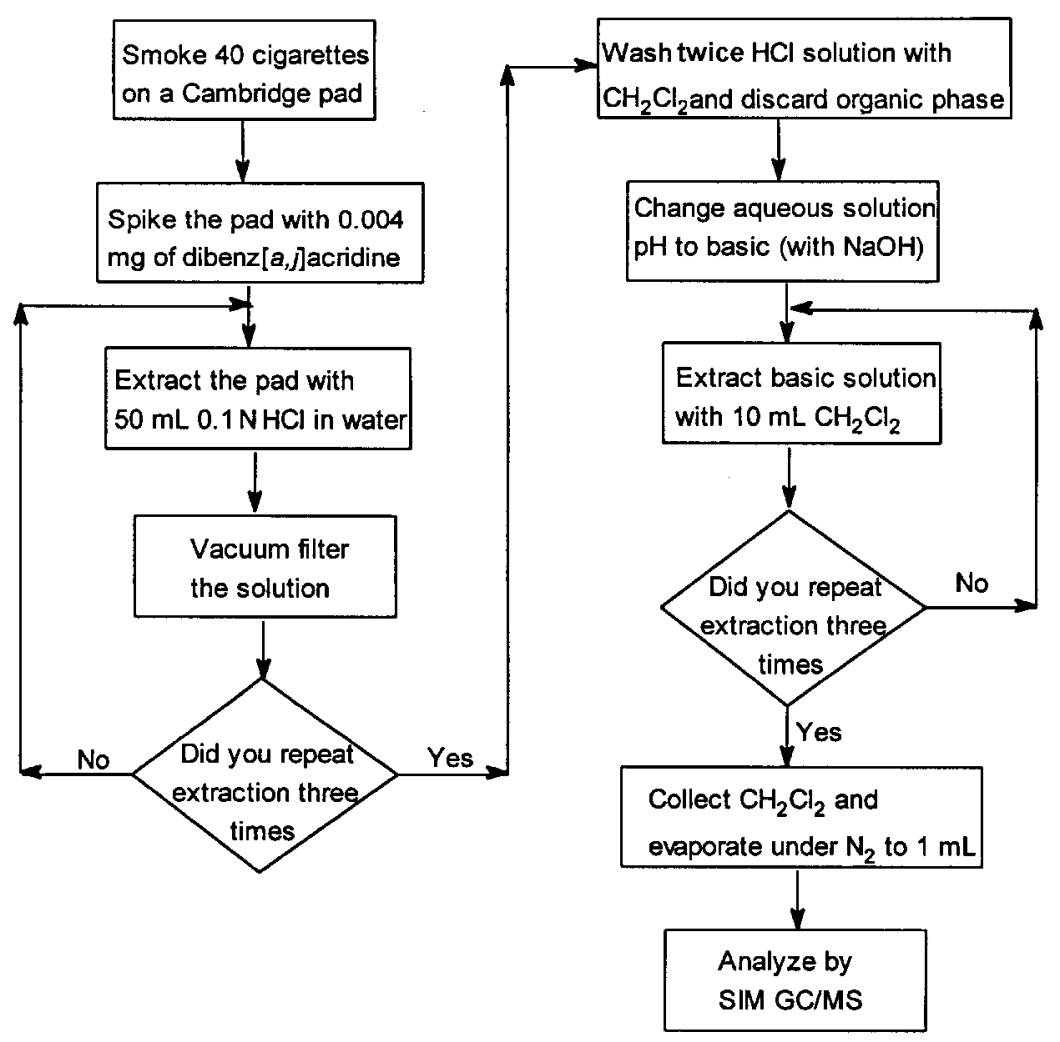

Figure 1.

Initial scheme for extraction of dibenzacridines from Cambridge pads. 


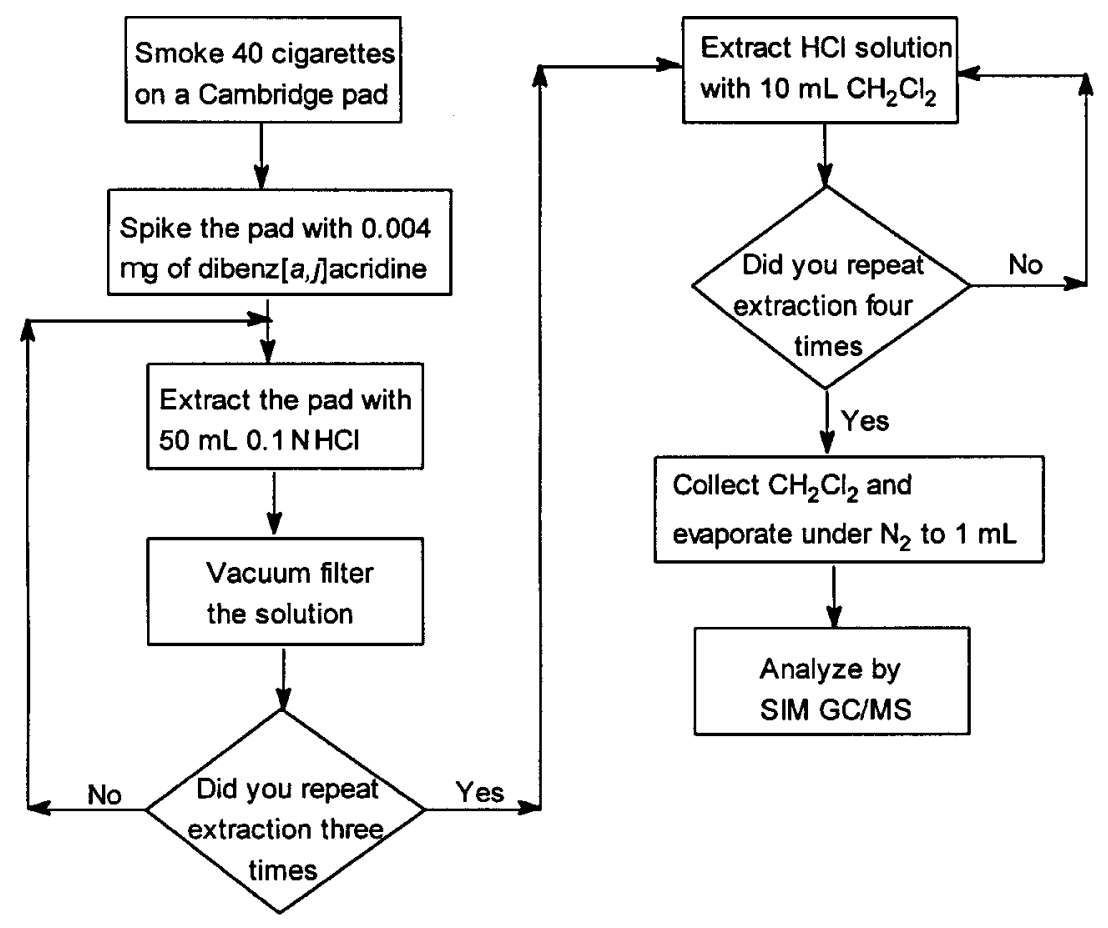

Figure 2.

Revised scheme for extraction of dibenzacridines from Cambridge pads.

the extraction procedure was modified. The modified technique, Scheme B, is shown in Figure 2. The main differences between Schemes $\mathrm{A}$ and $\mathrm{B}$ are the omission of the first $\mathrm{CH}_{2} \mathrm{Cl}_{2}$ wash as well as the step changing the $\mathrm{pH}$ of the aqueous solution from acidic to basic.

\section{Instrumentation}

Chromatography. All separations were performed on a $30 \mathrm{~m}$ BPX-5 column (SGE, Inc., Austin, TX, USA) with $0.25 \mathrm{~mm}$ i.d. and $0.25 \mu \mathrm{m}$ film thickness housed in an Hewlett Packard (HP) 6890 gas chromatograph. The initial temperature was $45^{\circ} \mathrm{C}$, held for 5 minutes, then increased $10^{\circ} \mathrm{C} / \mathrm{min}$ to a final temperature of $310^{\circ} \mathrm{C}$, where it was held for 5 minutes. The instrument was operated in constant flow mode $(2.0 \mathrm{~mL} / \mathrm{min})$ with helium as the carrier gas.

Detection. An HP 5973 mass selective detector (MSD) was used for detection. It was operated in selected ion monitoring (SIM) mode, monitoring $\mathrm{m} / \mathrm{z}=279$ for dibenzacridine and $m / z=292$ for dibenzacridine- $d_{13}$.

\section{RESULTS}

Extraction method

As previously mentioned, the initial extraction scheme was not successful in extracting the dibenzacridine standards, as they were being discarded with the first organic solvent wash. After the scheme was modified to
Scheme B, the standard was successfully extracted with very good efficiency.

The procedure in Scheme B was applied to various cigarette samples to determine if the standards could be extracted when in a cigarette smoke matrix. Figures $3 a$ and $3 \mathrm{~b}$ show the extracted ion chromatograms for $\mathrm{m} / \mathrm{z}=279$ and $\mathrm{m} / \mathrm{z}=292$, respectively, for a sample of 80 cigarettes (commercial cigarette A, $17.5 \mathrm{mg}$ tar) spiked with the equivalent of $10 \mathrm{ng} / \mathrm{cig}$. of each $\operatorname{diben} z[a, j]$ acridine, $\operatorname{diben} z[a, b]$ acridine, and dibenz $[a, j]$ acridine- $d_{13}$. These figures demonstrate that the extraction procedure is sufficient to analyze dibenzacridines that may be present in the particulate phase of tobacco smoke.

The procedure in Scheme B was also used in our initial attempts to analyze the particulate phase of cigarette smoke for $7 \mathrm{H}$-dibenzo[c,g]carbazole. Scheme B was inadequate for the extraction of dibenzo[ $[, g]$ carbazole from the Cambridge pad.

\section{Detection of dibenzacridines in particulate phase tobacco smoke}

Several different brands and styles of cigarette smoke were analyzed for the presence of dibenzacridines. To enhance the odds of detecting possible traces of dibenzacridines, up to 320 cigarettes were smoked, the particulate phase collected on eight pads. The pads were combined and extracted by Scheme B. One pad was spiked with the equivalent of $1.7 \mathrm{ng} / \mathrm{cig}$. dibenz $[a, j]$ acridine- $d_{13}$. Figures $4 \mathrm{a}$ and $4 \mathrm{~b}$ show the respective resulting extracted ion chromatograms for 

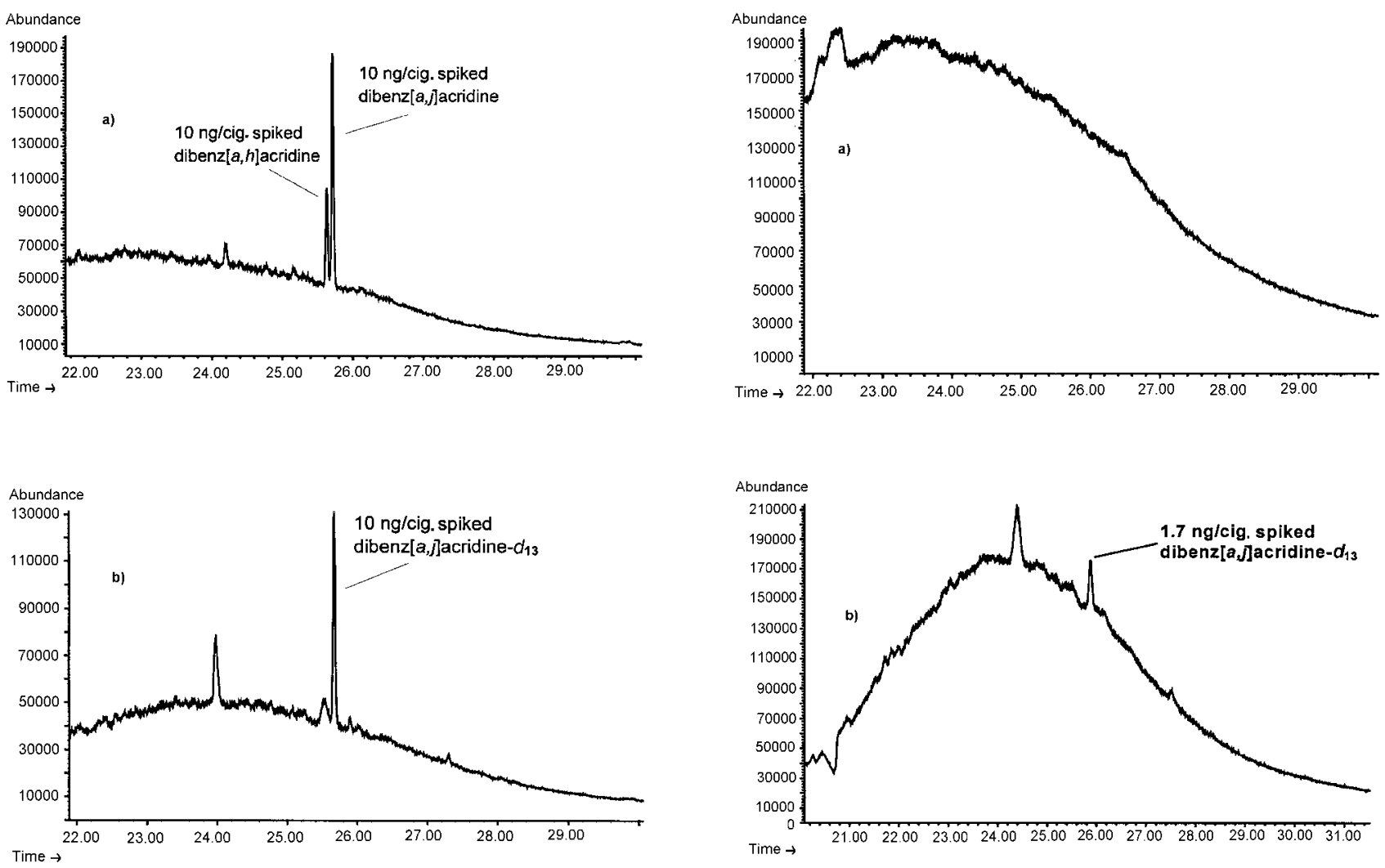

Figure 3.

Extracted ion chromatograms showing separation of the two dibenzacridine isomers and the deuterated compound. The particulate matter from 80 cigarettes were spiked with dibenz[a]]acridine, dibenz[a,h]acridine, and dibenz[aj]acridine- $d_{13}$. a) $m / z=279$; b) $m / z=292$

$m / z=279$ and $m / z=292$. Similar experiments were performed twice for cigarette $\mathrm{A}$ and also for commercial cigarettes $\mathrm{B}$ and $\mathrm{C}$ and a $1 \mathrm{R} 4 \mathrm{~F}$ cigarette.

Figures $5 \mathrm{a}$ and $5 \mathrm{~b}$ show the mass spectra for dibenz $[a, j]$ acridine and dibenz $[a, j]$ acridine- $d_{13}$, respectively. The lack of fragmentation in the mass spectra of dibenzacridines is a disadvantage regarding the presence of confirming ions for identification. However, it is advantageous from a sensitivity standpoint when SIM detection is utilized. The GC/MS technique developed for detection of dibenzacridines in this study was sensitive enough to quantitate as low as $1.7 \mathrm{ng} / \mathrm{cig}$. of dibenz $[a, j]$ acridine. It is very likely that detection without quantification can be accomplished at even lower levels.

\section{DISCUSSION}

Examination of the various figures presented indicates that the dibenzacridines are not present in smoke at levels higher than $1.5 \mathrm{ng} / \mathrm{cig}$. Also, it is very likely that if present at all in smoke, the level of these compounds is below 0.5

Figure 4.

Extracted ion chromatograms of smoke from 320 cigarettes spiked with the equivalent of $1.7 \mathrm{ng} / \mathrm{cig}$. of dibenz[aj]acridine- $\boldsymbol{d}_{13}$. a) $m / z=279$; b) $m / z=292$

$\mathrm{ng} / \mathrm{cig}$. This finding is in disagreement with the data reported by HOFFMANN and HOFFMANN (3).

Because of this discrepancy with previous results, a more detailed evaluation was made of the initial 1960 paper by VAN DUUREN et al., which indicated the presence of dibenzacridines in cigarette tar. In this paper, the authors started with $250 \mathrm{~g}$ of cigarette tar, which is relatively difficult to generate. Furthermore, the smoking conditions for generating the tar are not indicated in the original paper. However, the proposed separation by VAN DUUREN et al. basically follows Scheme A of the work presented here, which was proven to be inadequate for the analysis of dibenzacridines. In fact, in Scheme A the dibenzacridines were discarded with the organic solvent used to wash the acidic aqueous solution. Therefore, it is highly unlikely that the "basic fraction" separated by the procedure utilized by VAN DUUREN et al. can contain dibenzacridines.

Another possible source of ambiguity is the detection/ identification procedure utilized by VAN DUUREN $e t a l$. Identification was based on UV absorption spectra and fluorescence excitation spectra. Although the spectra presented in the paper are indeed similar to those of dibenzacridines, it is generally accepted that these types of spectra are not always conclusive for determining the presence of a specific compound. 

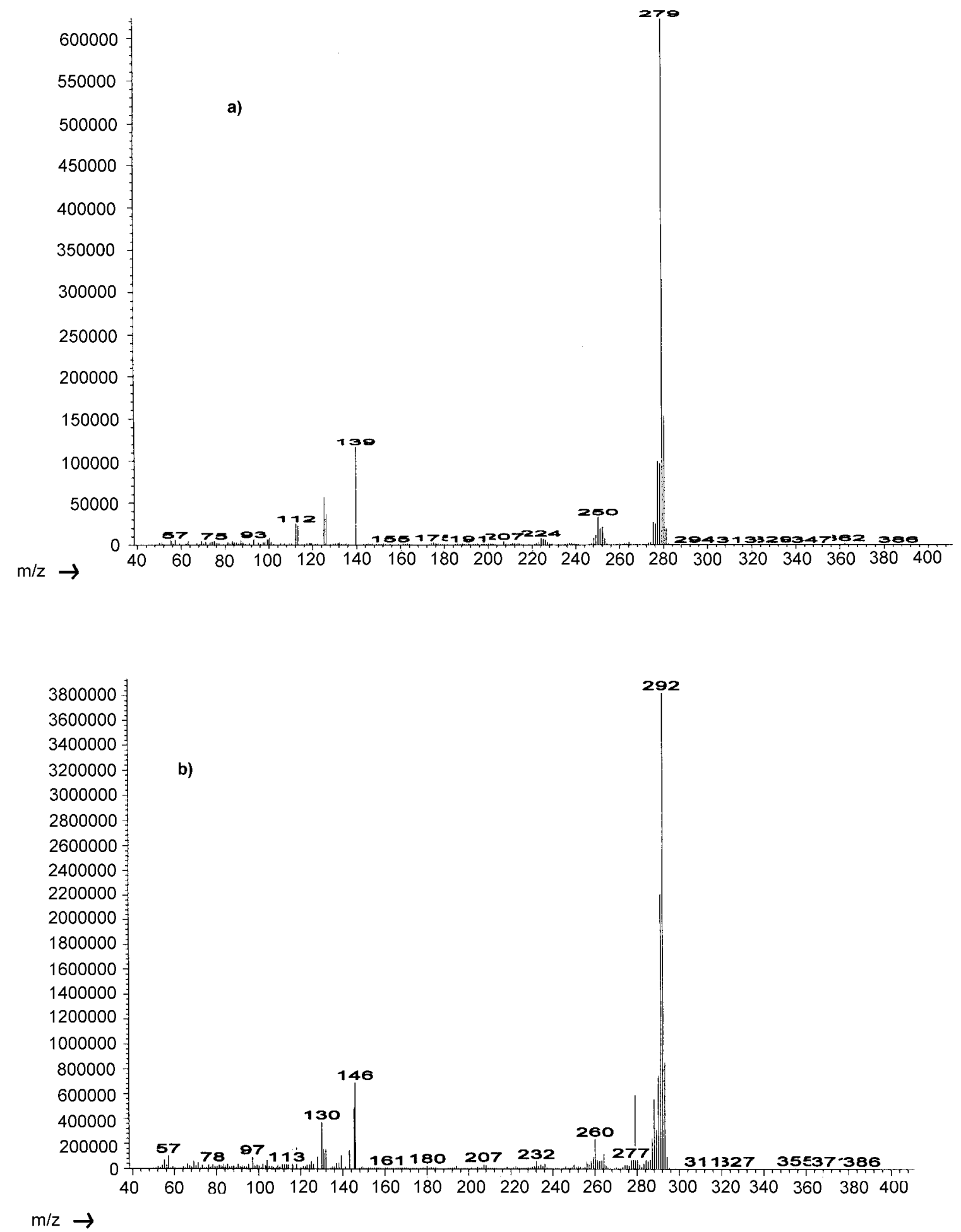

\section{Figure 5.}

El mass spectra of a) dibenz[aj]acridine and b) dibenz[a,j]acridine- $d_{13}$.

7H-Dibenzo[c,g]carbazole is also reported by VAN DUUREN et al. (1) as being detected in the basic fraction of the particulate phase of smoke. No evaluation of possible levels of $7 \mathrm{H}$-dibenzo[ $[, g]$ carbazole was done in this study because neither Scheme A nor Scheme B can be applied for its analysis, as the substance is not a basic compound (13). The verification of extraction path for dibenzo $[c, g]$ carbazole was done by spiking $4000 \mathrm{ng}$ of a dibenzo[c,g]carbazole standard on a clean Cambridge pad. After spiking, Scheme A was applied and each step monitored with fluorescence under UV light to check the path of the analyte. As expected, the acidic water solution was unable to extract dibenzo[c,g]carbazole from the Cambridge pad. Therefore, a completely 
separate extraction scheme is necessary to determine if this compound is present in the particulate phase of smoke and, if so, at what level.

\section{REFERENCES}

1. Van Duuren, B.L., J.A. Bilbao, and C.A. Joseph: The carcinogenic nitrogen heterocycles in cigarette smoke condensate; J. Natl. Cancer Inst. 25 (1960) 53-61.

2. Candeli, A., D. Hoffmann and E.L. Wynder: Unpublished 1963 data; in: Wynder, E.L., and D. Hoffmann: Experimental tobacco carcinogenesis; Adv. Cancer Res. 8 (1964) 249-453 (see pp. 323-333), Wynder, E.L., and D. Hoffmann: Tobacco and tobacco smoke: studies in experimental carcinogenesis; Academic Press, New York, N.Y., 1967, pp. 373-374, Table VIII 14.

3. Hoffmann, D., and I. Hoffmann: Tobacco smoke components; Beitr. Tabakforsch. Int 18 (1998) 49-52.

4. Rodgman, A.: Tobacco smoke components; Beitr. Tabakforsch. Int. 18 (1998) 127-129.

5. Kaburaki, Y., S. Sugawara, U. Kobashi, and T. Doihara: Studies on the composition of tobacco smoke, XIV: the formation of pyridines in the pyrolysis of nicotine; J. Agr. Chem. Soc. Japan 44 (1970) 224-231.

6. Schmeltz, I., W.S. Schlotzhauer, and E.B. Higman: Characteristic products from pyrolysis of nitrogenous oganic substances; Beitr. Tabakforsch. 6 (1972) 134-138.

7. Schmeltz, I., A. Wenger, D. Hoffmann, and T.C. Tso: Chemical studies on tobacco smoke, 63: on the fate of nicotine during pyrolysis and in a burning cigarette; J. Agr. Food Chem. 27 (1979) 602-608.
8. Snook, M.E.: Nitrogen analogues of polynuclear aromatic hydrocarbons in tobacco smoke; in: Carcinogenesis: polynuclear aromatic hydrocarbons, Vol. 3, edited by P.W. Jones and R.I. Freudenthal, Raven Press, New York, N.Y., 1978, pp. 203-215.

9. Snook, M.E., P.J. Fortson, and O.T. Chortyk: Isolation and identification of aza-arenes of tobacco smoke; Beitr. Tabakforsch. Int. 11 (1981) 67-78.

10. Grimmer, G., K.W. Naujack, and C. Dettbarn: Gas chromatographic determination of polycyclic aromatic hydrocarbons, aza-arenes, aromatic amines in the particle and vapor phase of mainstream and sidestream smoke of cigarettes; Proceedings of the International Experimental Toxicology Symposium on Passive Smoking, Essen, FRG, 1986, Toxicol. Lett. 35 (1987) 117-124.

11. Kamata, K., N. Motohashi, R. Meyer, and Y. Yamamoto: Analysis of benz[c]acridines in cigarette smoke by high-performance liquid chromatography; J. Liq. Chromatog. 15 (1992) 1907-1921.

12. Baker, R.R.: Smoke chemistry; in: Tobacco: production, chemistry, and technology, edited by D.L. Davis and M.T. Nielson, Blackwell Science, Berlin, 1999, pp. 398-432.

13. Elderfield, R.C.: Heterocyclic compounds, Vol. 1; John Wiley, New York, N.Y., 1950.

Address for correspondence:

Brown and Williamson Tobacco Corp.

2600 Weaver $\mathrm{R} d$.

P.O. Box 1056

USA - Macon, GA 31217 